\title{
Transformative Pedagogy as a Way of Mitigating School Violence in Public Secondary Schools in Nairobi, Kenya
}

\author{
Olivia A. Opere, Isabella Kamere, Violet Wawire \\ Department of Educational Foundations, Kenyatta University, Nairobi City, Kenya \\ Email: oliviaopere@gmail.com, opere.olivia@ku.ac.ke,imkamere@yahoo.com,wawire.violet@gmail.com
}

How to cite this paper: Opere, O. A., Kamere, I., \& Wawire, V. (2020). Transformative Pedagogy as a Way of Mitigating School Violence in Public Secondary Schools in Nairobi, Kenya. Open Journal of Social Sciences, 8, 35-52.

https://doi.org/10.4236/jss.2020.87004

Received: April 12, 2020

Accepted: July 6, 2020

Published: July 9, 2020

Copyright $\odot 2020$ by author(s) and Scientific Research Publishing Inc. This work is licensed under the Creative Commons Attribution International License (CC BY 4.0).

http://creativecommons.org/licenses/by/4.0/

\section{(c) (i) Open Access}

\begin{abstract}
The prevalence of school violence (SV) in public secondary schools in Kenya has resulted into injuries, loss of property and sometimes death. Penalties meted out on students ranging from fines on students, suspension or expulsion of students from school has been introduced in vain. Several commissions of inquiry have also been put in place to address this issue but not much has been achieved. Violence negatively affects students hence the need to identify ways of mitigating school violence. This study argues that to a large extent, school violence in public secondary schools is due to either the absence or limited use of transformative pedagogy (TP) which provides the learners with an opportunity for critical thinking, enables behavioural change and the inculcation of values hence the attainment of peaceful coexistence amongst students. Using Mezirow's Transformative learning theory, the study adopted a Mixed Method Research methodology in which data was drawn from 426 respondents comprising 341 students and 85 teachers in 22 public secondary schools in Nairobi County, 28 Key informants and 7 Focus Group Discussions (FGDs). Data analysis was done using SPSS and N-vivo analysis techniques. The study found out that discussion groups and role play were the major learner centred teaching approaches used in the schools. The paper concluded that effective use of transformative pedagogical approaches positively influences behaviour change in students hence the attainment of a non-violent school community. The study recommended a review of the secondary school curriculum to adopt transformative teaching approaches as opposed to teacher centred learning.
\end{abstract}

\section{Keywords}

Transformative Pedagogy, School Violence, Peaceful Coexistence 


\section{Introduction}

Transformative Pedagogy shapes attitudes and equips learners with the knowledge and skills they require to peacefully coexist. The approaches in the context of peace education (PE) should ensure the experience impacts on the learners' actions thereby transforming their behavior. In Kenya, SV in public secondary schools is on the rise, hence the need for a sustainable solution to the problem. It involves physical or verbal interpersonal aggression between students, by teachers on their students or vice versa and destruction of school property. The specific forms of violence may include strikes and arson attacks, bullying, sexual harassment, corporal punishment, verbal abuse and ethnic violence. The first incidence of SV was reported at Maseno school in 1908 and since then, there has been an upsurge of violence in public secondary schools in Kenya. Further, in the 1990s through to the 2000s SV has resulted into loss of lives, burning of schools and massive destruction of school property (Kirioba, 2012). The affected institutions and the government by extension, have responded by imposing penalties of various proportions ranging from closures of schools, fines, suspension and sometimes expulsion of students from school. In spite of the tough measures meted out on the students, not much has been achieved. Instead SV is still prevalent in public secondary schools in Kenya. Not only do students lose a lot from the interrupted learning but they also end up transiting into the society, after school, to become adults who are prone to violence and are therefore social misfits. Managing the conduct of students at school through a curriculum that is based on transformative teaching and learning, is therefore critical because it eventually impacts on the larger community and vice versa. TP empowers learners with knowledge and skills to critically think of how to solve problems they encounter. They acquire conflict resolution skills and values such as respect and teamwork. TP creates space within the classroom for dialogue sothat learnersrealise their own capacity to make a better world for all people (McAllister, 2015). This eventually ensures the achievement of sustainable peace, since parties involved have to interact with a view to understanding each other, collaborating and cooperating.

A progressive approach to managing behavior considers students' conduct as manifestations of a developmental need. Further, explicit teaching of values such as self-regulation, conflict resolution nurtures responsible behavior (DarlingHammond et al., 2020). Education is expected to provide learners with critical skills through which they adopt dialogue and discussion as constructive and peaceful means to conflict resolution in society (Pherali, 2019). In Indonesia, the school curriculum focuses on shaping social attitudes to inculcate values such as mutual respect, kindness and tolerance (Hermino, 2017). Such initiatives show that there exist education-based peace initiatives geared towards the elimination of SV using transformative learning. In Rwanda, where education was used for discrimination and marginalisation throughout its history it now plays a critical role in building up national unity and reconciliation in the post-genocide education re- 
forms. It not only contributes to the literature on education and conflict but also transforms the values of learners (Taka, 2020).

Transformative learning which involves the use of pedagogy of deep listening as a teaching technique allows a teacher to listen deeply to learners' internal and external environments, nurture a generative co-creative space for them to process experiences, deepen their knowledge of what is known and unknown, and manage any disorienting perspectives (Laryea, 2018). A state of tranquility where violence does not exist and whenever conflict arises, non-violent strategies are used to achieve peaceful coexistenceis achieved. This paper discusses ways in which the behaviour of learners could be modelled to allow for efficient and effective management of SV in public secondary schools and by extension the community. It argues that TP is vital for the acquisition of knowledge, skills and values which enables change of behavior necessary for embracing peaceful coexistence.

\section{Analytical Framework}

This study conceptualizes TP as a process of transmitting knowledge, values and skills for the transformation of behaviour to enable living in harmony and peacefully with oneself and others in asecure environment. It supports the development of functional levels of emotional, psychological, and social well-being of learners. It is a learner-centred approach which focuses on the learner, endows them with the ability to influence social change and enriches their views of interpersonal relationships and interactions with other members of the school community. The paper argues that to a large extent, the violence witnessed in public secondary schools have been occasioned by either the absence of or limited TP in public secondary schools. If further suggests that the more innovative teaching and learning approaches are used to enable the acquisition of knowledge and skills on peace building, the more likely the learners will embrace peace values and peaceful coexistence amongst them and the community. A classroom environment where participatory and democratic learning enabling learners to construct new interpretations of experiences in their world, make informed choices, and demonstrate tolerance is practiced promotes peaceful coexistence. It also imbibes the students governing body with good leadership skills. This goes a long way in facilitating the overall effective governance and management of the public schools. If schools are well managed, there is bound to be no unrests and subsequent property damage, injuries and sometimes death of the learners.

The paper has adopted Jack Mezirow's Transformative Learning Theory to gain insights concerning the use of appropriate teaching and learning approaches to prepare learners who appreciate the value of peaceful coexistence. Transformative Learning theory argues that human beings can change their behaviour after going through psychological and convictional processes. The theory postulates that a learner's experience is not only central but also the starting point 
and the subject matter for transformative learning (Mezirow, 2009). Experience being socially constructed, can also be deconstructed and acted upon by the teacher engaging learners in personal reflections and group discussions through the stimulation of uncertainty, ambiguity, and doubt about previously taken for granted interpretations of various human actions.

The second assumption is that critical reflection is the distinguishing characteristic of adult learning by way of being made aware of the "uncritically assimilated half-truths of conventional wisdom and power relationships. It often occurs in response to an awareness of a contradiction among our thoughts, feelings, and actions resulting from distorted epistemic, psychological, and sociolinguistic assumptions. The third is that rational discourse is the essential medium through which transformation is promoted and developed (Mezirow, 2009).

Jack Mezirow's transformative learning theory therefore presents learning as involving a shift in basic principles of thought and actions. The theory explains how human beings use critical self-reflection to review their beliefs and experiences and eventually change whatever is considered dysfunctional. The aim of transformative learning is therefore to encourage learners to have a mental and behavioral shift with the intention of influencing their value systems. The theory argues that learning can be acquired through self-reflection and rationality which results in the disruption of previous experience based on societal values, moral principles and parental guidance to create space for the construction of new ideas as communicated by the teacher based on particular delivery styles and content, which finally results in the learner's behavioral change in terms of attitude, self-perception, and principles of moral values. Jack Mezirow in his theory of transformative learning argues that in addition to acquisition of knowledge, the learning process should entail critical reflection on issues, exploration of alternatives, building of competencies and integration of skills acquired into an individual's way of life (Mezirow, 2009).

Applied to this study, the theory argues that transformative learning mechanism can contribute to removal or deconstruction of preexisting violent behaviour through transformative learning approaches of peace values, moral principles involving group discussions, role plays, self-reflection that results in positive behaviourial change as and achieving peaceful coexistence among students/learners within public secondary schools in Kenya. Transformative learning therefore enables the inculcation of values such as mutual respect and cooperation through integration in the school rules and the textbooks to enable acquisition of knowledge for behavioural change towards attaining peaceful coexistence through mutual toleration of each other leading to harmonious coexistence.

\section{Methodology}

\subsection{Research Design}

This study adopted a cross-sectional research design and employed a mixed me- 
thod methodology (Creswell, 2014). This approach involved a concurrent qualitative and quantitative approach administered through a survey questionnaire, Focus Group Discussions (FGDs) and observation sessions to determine the teaching approaches used in public secondary schools. For a more comprehensive and in-depth understanding of the research problem, quantitative data and qualitative data was triangulated.

The study was conducted in 10 administrative sub-counties of Nairobi County namely; Kasarani, Kibra, Westlands, Dagorretti, Langata, Kamkunji. Njiru, Embakasi, Kamkunji and Makadara. Nairobi County was selected for being cosmopolitan therefore prone to ethnic based violence. Secondly, because of the existence of areas such as Kibera and Mathare which are considered hotspots because of the frequent eruptions of violence whenever political disputes arise in Kenya.

Respondents from seven (7) categories of schools, namely, Boys' Boarding (BB), Girls’ Boarding (GB), Boys' Day (BD), Girls' Day (GD), Coeducational Day. (CD), Coeducational Day/Boarding (CD\&B), and Boys' Boarding/Day (BB\&D) were targeted. The study employed various sampling techniques. Purposive sampling was used to identify Nairobi due to its heterogeneity and the fact that it possesses all the desired characteristics and categories from a population of 63 public secondary schools.

Nairobi County consists of 27 Day Schools and 36 Boarding schools. Stratified sampling technique was used to identify public secondary schools based on the seven (7) categories. From each stratum, the secondary schools were further stratified into boys' only and girls "only schools taking into consideration the fact that there is only one girls" day and one Coeducational "boarding and boys" day public secondary schools in this County. From each of the seven (7) categories of schools the strata/substrata was identified as follows: Boys' Boarding schools (5): Girls Day school: (1); Girls’ Boarding; Boys Day School (2); Coeducational Day Schools (7) Coeducational day/boarding School (1), Boys Boarding/day School (1). The stratification process took into consideration the diversities in gender and categories of school. This technique accorded every student in the sample an equal chance of being selected as a participant (Bartlett et al., 2001). Respondents were sampled from each of the identified schools. The lottery method was used to select the required $30 \%$ percent from each cluster of the seven categories of public secondary schools.

The total number of students in the public secondary schools within Nairobi County was 69,934. The sample size was determined using Krejcie-Morgan-sample-size-table which was developed by Krejcie and Morgan at confidence level of 95 per cent and a margin of error of 5 per cent is 384 (Krejcie \& Morgan, 1970). From each of the 22 schools, an average of 19 respondents (teachers and students) were sampled giving a total sample size of 426 respondents. Based on the teacher student ratio 20\% (85) of the teachers and 341 students were interviewed. An average of four teachers per school were iden- 
tified based on their role in implementing peace education programmes in their respective schools. The teachers held various positions of responsibility in their respective schools including being class teachers, heads of department and club leaders. Students who participated in the study were randomly selected from all the class levels, some of them were club leaders and others prefects.

The sample comprised 426 respondents, 85 teachers and 341 students drawn from 22 secondary schools. The sample size in the seven categories of secondary schools were as follows: Boys Boarding (101), Girls Boarding (90), Boys Day (65), Girls Day (21), and Mixed Day (116). Mixed Day/Boarding (14), and Boys Boarding/Day (19) as shown in Table 1.

\subsection{Data Collection and Analysis}

The following research instruments were used to collect data from a variety of sources: Survey Questionnaires, Key informant interviews Schedule, Focus Group Discussion Schedule, Non-participant Observation Guide, Content Analysis Schedules. Data was coded, entered and cleaned ready for processing and analysis using descriptive statistics in Statistical Packages for Social Science (SPSS 21). Cross tabulations of the responses obtained were used to generate relevant information and to establish the general trend of findings on the various variables that were under investigation and the findings presented using

Table 1. The number of respondents by category of school and sub-county.

\begin{tabular}{|c|c|c|c|c|c|c|c|c|}
\hline \multirow{2}{*}{$\begin{array}{c}\text { Name of Sub } \\
\text { county }\end{array}$} & \multicolumn{7}{|c|}{ Categories of Public Secondary schools in Nairobi County } & \multirow{2}{*}{$\begin{array}{l}\text { Number of } \\
\text { Respondents }\end{array}$} \\
\hline & $\begin{array}{c}\text { Boys } \\
\text { Boarding }\end{array}$ & $\begin{array}{c}\text { Girls } \\
\text { Boarding }\end{array}$ & Boys Day & Girls Day & Mixed Day & $\begin{array}{l}\text { Mixed Day } \\
\text { \& Boarding }\end{array}$ & $\begin{array}{c}\text { Boys } \\
\text { Boarding/Day }\end{array}$ & \\
\hline Kibra & 0 & 0 & 0 & 0 & 31 & 0 & 0 & 31 \\
\hline Embakasi & 0 & 0 & 22 & 0 & 47 & 0 & 0 & 69 \\
\hline Njiru & 22 & 0 & 20 & 0 & 17 & 0 & 0 & 59 \\
\hline Starehe & 0 & 37 & 0 & 0 & 0 & 0 & 19 & 56 \\
\hline Dagoretti & 18 & 0 & 0 & 0 & 21 & 0 & 0 & 39 \\
\hline Makadara & 39 & 38 & 0 & 0 & 0 & 0 & 0 & 77 \\
\hline Westlands & 0 & 15 & 0 & 0 & 0 & 0 & 0 & 15 \\
\hline Langata & 22 & 0 & 0 & 0 & 0 & 0 & 0 & 22 \\
\hline Kasarani & 0 & 0 & 0 & 21 & 0 & 0 & 0 & 21 \\
\hline Total & 101 & 90 & 65 & 21 & 116 & 14 & 19 & 426 \\
\hline
\end{tabular}

Compiled by Author. 
percentages and tables.

\section{Results and Discussions}

In order to establish the extent to which $\mathrm{TP}$ promotes peaceful coexistence among learners in public secondary schools, the study examined the secondary school curriculum for teaching approaches and peace content.

\subsection{Teaching Approaches}

Effective teaching and learning shapes attitudes and equips learners with the skills they require to address issues which cause conflict leading to violence. In order to establish if the teaching and learning approaches used by teachers promote peaceful co-existence amongst students, respondents were asked to state the extent to which they agreed that the methods applied by the teachers promote peaceful co-existence. Classroom observations were also conducted to observe the mode of content delivery.

The mode of delivery is key to passing peace messages. Transformative Pedagogy is learner-centred and experiential. It therefore makes use of democratic and participatory techniques such as role play, group discussions in which the learner is actively involved in the teaching and learning process and is not just a passive participant who merely listens to the teacher. It also involves infusion of peace values. Employing such techniques ensures learners acquire problem solving skills, ability to handle problematic social dealings such as fights and verbal abuse which they encounter as they interact with others. It enhances critical thinking and enables internalization of peace values such as forgiveness and empathy.

\subsection{Integrating Peace Education Content during Teaching and Learning Sessions}

The study inquired from the respondents the extent to which they agreed or did not agree that PE Content was integrated during the teaching and learning sessions. Cross tabulation by class levels provided results as shown in $\mathrm{Ta}$ ble 2 .

Table 2 illustrates that $74.4 \%$ agreed and $15.3 \%$ disagreed that teachers integrated PE content. On average, form two students at $21.6 \%$ presented the highest proportion of respondents who agreed that teachers integrate peace content during the teaching and learning sessions followed by Form Four students at $19.8 \%$ and the least being Form Threes at 15.6\%. It was necessary to find out why although a large percentage of informants reported that teachers used teaching approaches which promote peaceful coexistence, violence was still prevalent in secondary schools. FGDs held with students and interviews with the school principals revealed that the reason why these learners were involved in violence in spite of their teachers infusing PE content during the lessons is that the mode of delivery was ineffective. 
Table 2. Integration of peace education content during teaching and learning sessions.

\begin{tabular}{|c|c|c|c|c|c|}
\hline \multicolumn{6}{|c|}{ Do teachers include PE content during teaching and learning sessions? } \\
\hline \multirow{2}{*}{ Level of Agreement } & \multicolumn{4}{|c|}{ Class } & \multirow{2}{*}{ Total } \\
\hline & Form 1 & Form 2 & Form 3 & Form 4 & \\
\hline \multirow{2}{*}{ Strongly Agree } & 26 & 40 & 26 & 25 & 117 \\
\hline & $7.8 \%$ & $12.0 \%$ & $7.8 \%$ & $7.5 \%$ & $35.1 \%$ \\
\hline \multirow{2}{*}{ Agree } & 32 & 32 & 26 & 41 & 131 \\
\hline & $9.6 \%$ & $9.6 \%$ & $7.8 \%$ & $12.3 \%$ & $39.3 \%$ \\
\hline \multirow[b]{2}{*}{ Undecided } & 8 & 3 & 13 & 10 & 34 \\
\hline & $2.4 \%$ & $0.9 \%$ & $3.9 \%$ & $3.0 \%$ & $10.2 \%$ \\
\hline \multirow[b]{2}{*}{ Disagree } & 4 & 4 & 9 & 11 & 28 \\
\hline & $1.2 \%$ & $1.2 \%$ & $2.7 \%$ & $3.3 \%$ & $8.4 \%$ \\
\hline \multirow{2}{*}{ Strongly Disagree } & 1 & 2 & 8 & 12 & 23 \\
\hline & $0.3 \%$ & $0.6 \%$ & $2.4 \%$ & $3.6 \%$ & $6.9 \%$ \\
\hline \multirow[b]{2}{*}{ Total } & 71 & 81 & 82 & 99 & 333 \\
\hline & $21.3 \%$ & $24.3 \%$ & $24.6 \%$ & $29.7 \%$ & $100.0 \%$ \\
\hline
\end{tabular}

The discussants were of the opinion that the peace values were not explicitly highlighted and no effort was made to relate the content to their day to day lives in a manner that they could resonate with the PE content. The school principals who commented on this laid blame on an education system which is not value based but instead examination orientated and therefore teaching happened for the sake of learners passing examinations but not to mould their characters into respectful and emphatic human beings. One of the school principals said:

"Teachers are dedicated to ensure the syllabus is covered in time for revision so that students can pass examinations. They are unable to focus on instilling moral values at the expense of teaching examinable subjects" (Key informant, Secondary School Principal, BB School, $1^{\text {st }}$ August, 2018).

These views explain why SV is prevalent in spite of what the informants consider an effort by the teachers to incorporate PE content as they teach. This is consistent with revelations in a study to determine the effects of integrating PE in the Nigeria education system, which concluded that mainstreaming PE content into the curriculum requires the use of peace based instructional methods and strategies. Such methods and strategies are geared towards promoting interactive learning processes such as peer teaching, mediation and problem solving (Olowo, 2016). It is evident from the findings that the realization that learning is deeper and impactful when concepts are substantiated with relevant real life examples and learners are given an opportunity to reflect upon whatever 
they have been taught is lacking.

\subsection{Mode of Delivery of Peace Education Content}

The mode of delivery of messages or concepts which promote peace is key. Teachers play a vital role in engaging learners in interactions which enable critical thinking. The study sought to find out if the method of delivery of PE content by teachers promotes peaceful coexistence. The respondents were asked to state the extent to which they agreed or not with the assertion that the mode of delivery of the PE content promotes peaceful co-existence. The responses by school categories were cross tabulated and results shown in Table 3.

Table 3 shows that only $25 \%$ of the respondents felt that the mode of delivery of content used by teachers promote peaceful coexistence while $57.4 \%$ disagreed. Out of those who felt that the mode of delivery promotes peaceful co-existence, at $16.9 \%$ were in coeducational day schools followed by boys' boarding at $13.5 \%$ and girls' boarding at $10.8 \%$. Bearingin mind that prevalence of violence is said to be high in coeducational schools (Opere et al., 2019) this finding shows that PE content although available, was not being delivered appropriately to enable positive change of behavior. The study further set out to find out the perceptions of learners at various class levels on whether the mode of delivery of PE content promotes peaceful coexistence. They were asked whether the mode of delivery of PE content promotes peaceful coexistence. Table 4 and Figure 1 illustrates the responses.

Table 3. Mode of delivery of peace education content.

\begin{tabular}{|c|c|c|c|c|c|c|c|c|}
\hline \multirow{2}{*}{$\begin{array}{c}\text { Level of } \\
\text { Agreement }\end{array}$} & \multicolumn{7}{|c|}{ Category of School } & \multirow{2}{*}{ Total } \\
\hline & BB & GB & $\mathrm{BD}$ & GD & $\mathrm{CD}$ & $\mathrm{CD} \& \mathrm{~B}$ & $\mathrm{BB} \& \mathrm{D}$ & \\
\hline \multirow{2}{*}{ Strongly Agree } & 6 & 14 & 4 & 2 & 9 & 1 & 1 & 37 \\
\hline & $1.5 \%$ & $3.4 \%$ & $1.0 \%$ & $0.5 \%$ & $2.2 \%$ & $0.2 \%$ & $0.2 \%$ & $9.1 \%$ \\
\hline \multirow[b]{2}{*}{ Agree } & 21 & 11 & 8 & 2 & 15 & 2 & 6 & 65 \\
\hline & $5.1 \%$ & $2.7 \%$ & $2.0 \%$ & $0.5 \%$ & $3.7 \%$ & $0.5 \%$ & $1.5 \%$ & $15.9 \%$ \\
\hline \multirow{2}{*}{ Undecided } & 12 & 16 & 12 & 5 & 21 & 3 & 3 & 72 \\
\hline & $2.9 \%$ & $3.9 \%$ & $2.9 \%$ & $1.2 \%$ & $5.1 \%$ & $0.7 \%$ & $0.7 \%$ & $17.6 \%$ \\
\hline \multirow{2}{*}{ Disagree } & 27 & 27 & 22 & 8 & 42 & 5 & 4 & 135 \\
\hline & $6.6 \%$ & $6.6 \%$ & $5.4 \%$ & $2.0 \%$ & $10.3 \%$ & $1.2 \%$ & $1.0 \%$ & $33.1 \%$ \\
\hline \multirow{2}{*}{ Strongly Disagree } & 28 & 17 & 19 & 4 & 25 & 3 & 3 & 99 \\
\hline & $6.9 \%$ & $4.2 \%$ & $4.7 \%$ & $1.0 \%$ & $6.1 \%$ & $0.7 \%$ & $0.7 \%$ & $24.3 \%$ \\
\hline \multirow{2}{*}{ Total } & 94 & 85 & 65 & 21 & 112 & 14 & 17 & 408 \\
\hline & $23.0 \%$ & $20.8 \%$ & $15.9 \%$ & $5.1 \%$ & $27.5 \%$ & $3.4 \%$ & $4.2 \%$ & $100.0 \%$ \\
\hline
\end{tabular}

BB-Boys' Boarding; GB-Girls' Boarding; BD—Boys' Day; GD—Girls' Day; CD—Coeducational day; CDD\&B-Coeducational Day \& Boarding; BB\&D-Boys' Boarding \& Day. 


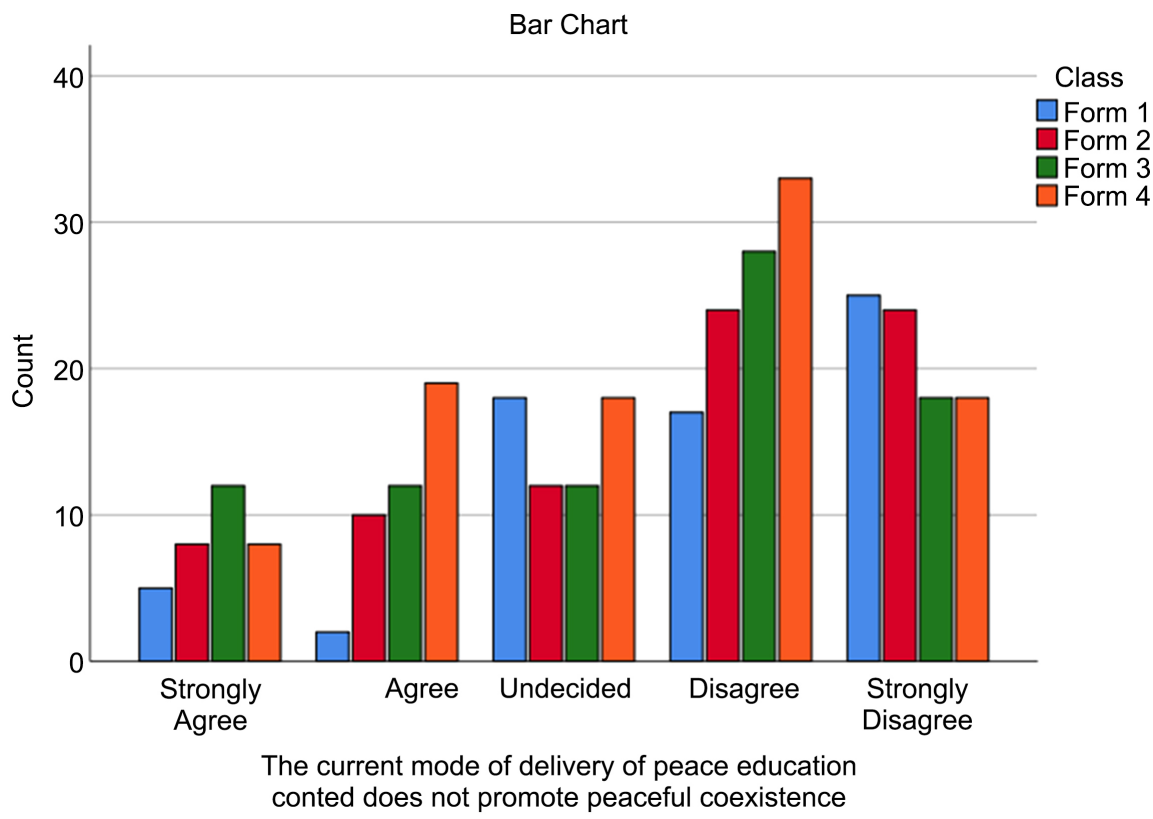

Figure 1. The mode of delivery of peace education content promotes peaceful co-existence.

Table 4. Perceptions of students on the mode of delivery of peace education content.

\begin{tabular}{|c|c|c|c|c|c|}
\hline \multirow{2}{*}{ Level of Agreement } & \multicolumn{4}{|c|}{ Class levels } & \multirow{2}{*}{ Total } \\
\hline & Form 1 & Form 2 & Form 3 & Form 4 & \\
\hline \multirow{2}{*}{ Strongly Agree } & 5 & 8 & 12 & 8 & 33 \\
\hline & $1.5 \%$ & $2.5 \%$ & $3.7 \%$ & $2.5 \%$ & $10.2 \%$ \\
\hline \multirow[b]{2}{*}{ Agree } & 2 & 10 & 12 & 19 & 43 \\
\hline & $0.6 \%$ & $3.1 \%$ & $37 \%$ & $5.9 \%$ & $13.3 \%$ \\
\hline \multirow[b]{2}{*}{ Undecided } & 18 & 12 & 12 & 18 & 60 \\
\hline & $5.6 \%$ & $3.7 \%$ & $3.7 \%$ & $5.6 \%$ & $18.6 \%$ \\
\hline \multirow[b]{2}{*}{ Disagree } & 17 & 24 & 28 & 33 & 102 \\
\hline & $5.3 \%$ & $7.4 \%$ & $8.7 \%$ & $10.2 \%$ & $31.6 \%$ \\
\hline \multirow{2}{*}{ Strongly Disagree } & 25 & 24 & 18 & 18 & 85 \\
\hline & $7.7 \%$ & $7.4 \%$ & $5.6 \%$ & $5.6 \%$ & $26.3 \%$ \\
\hline \multirow{2}{*}{ Total } & 67 & 78 & 82 & 96 & 323 \\
\hline & $20.7 \%$ & $24.1 \%$ & $25.4 \%$ & $29.7 \%$ & $100.0 \%$ \\
\hline
\end{tabular}

Table 4 and Figure 1 show that a larger percentage of students either disagreed, (31.5\%), or strongly disagreed, (26.3\%), that the mode of delivery of PE content promotes peaceful coexistence. This means that although the learners acknowledged that their teachers incorporated PE concepts, most of them felt that the manner in which this information was delivered did not enable them to 
critically think about issues that cause violence and to acquire conflict resolution skills. It is also evident that majority of students who felt that the current teaching approaches do not promote peaceful coexistence were in form four at $8.4 \%$ followed by form three at $7.4 \%$. At $2.1 \%$, form ones provided the least proportion of respondent who were of the opinion that the methods of teaching do not promote peaceful coexistence. To seek further clarification this issue was discussed in a Focus Group Discussion and a Form One student in one of the coeducational day schools had this to say:

"Our teachers unlike those of primary school just come to class and teach quickly then they go away. It is very different from primary school here. But I hope we shall get used to it. They do not even write notes on the blackboard, it is as if they are in a hurry to go away" (Form one female student,

GB school, FGD 1, $5^{\text {th }}$ July 2018).

This revelation points to the fact that the form one students' expectations have not been met in as far as the methods of teaching are concerned. They prefer the individualized attention they received from their teachers in primary school. A deliberate effort should be made by the form one teachers to put the PE content into perspective and to use transformative teaching and learning techniques which seek to in calculate values such as forgiveness, cohesion and mutual respect for peaceful coexistence. This would ensure the learners not only interact with others to enhance interpersonal relationships but with their teachers too for a conducive learning environment.

\subsection{Learner-Centred Teaching Approaches}

Traditionally teachers are considered as the sole source of knowledge and therefore the learner plays a passive role as a recipient of the information delivered by the teacher. This teacher centred approach does not allow the learner to be a critical thinker. A learner centred methodology in which the teaching and learning process is driven by the learner enables active learning. TP which is learner centred equips learners with problem solving skills which they require for avoid conflict. In order to find out the extent to which teachers used learner-centred teaching approaches in the delivery of PE content, the respondents were asked to state if they agreed or not that the learner-centred teaching methods discouraged SV. The responses were cross tabulated and results shown in Table 5.

Table 5 shows that $17.4 \%$ of the respondents, the highest, who felt that teachers used learner-centred methods were form four students while the lowest at $9.8 \%$ were in those in form one. Out of the $23.7 \%$ who did not agree, majority, at $7.2 \%$ were in form three followed by form fours at $6.3 \%$. The findings seem to suggest that teacher centred methods of teaching were preferred as opposed to those focused on the learner. To clarify this information, one of the school principals explained: 
Table 5. Learner-centred teaching approaches to discourage school violence.

\begin{tabular}{|c|c|c|c|c|c|}
\hline \multirow{2}{*}{$\begin{array}{c}\text { Levels of } \\
\text { Agreement }\end{array}$} & \multicolumn{4}{|c|}{ Class } & \multirow{2}{*}{ Total } \\
\hline & Form 1 & Form 2 & Form 3 & Form 4 & \\
\hline \multirow{2}{*}{ Strongly Agree } & 10 & 21 & 14 & 17 & 62 \\
\hline & $3.2 \%$ & $6.6 \%$ & $4.4 \%$ & $5.4 \%$ & $19.6 \%$ \\
\hline \multirow{2}{*}{ Agree } & 21 & 28 & 22 & 38 & 109 \\
\hline & $6.6 \%$ & $8.9 \%$ & $7.0 \%$ & $12.0 \%$ & $34.5 \%$ \\
\hline \multirow[b]{2}{*}{ Undecided } & 19 & 13 & 20 & 18 & 70 \\
\hline & $6.0 \%$ & $4.1 \%$ & $6.3 \%$ & $5.7 \%$ & $22.2 \%$ \\
\hline \multirow{2}{*}{ Disagree } & 13 & 12 & 15 & 11 & 51 \\
\hline & $4.1 \%$ & $3.8 \%$ & $4.7 \%$ & $3.5 \%$ & $16.1 \%$ \\
\hline \multirow{2}{*}{ Strongly Disagree } & 5 & 2 & 8 & 9 & 24 \\
\hline & $1.6 \%$ & $0.6 \%$ & $2.5 \%$ & $2.8 \%$ & $7.6 \%$ \\
\hline \multirow{2}{*}{ Total } & 68 & 76 & 79 & 93 & 316 \\
\hline & $21.5 \%$ & $24.1 \%$ & $25.0 \%$ & $29.4 \%$ & $100.0 \%$ \\
\hline
\end{tabular}

"Teachers are expected to use learner based methods of teaching for better engagement of learners and enhanced learning. We try to do that but the challenge of course is the big class sizes which do not allow for individualized attention" (Key informant, School Principal, Boys' day school, $10^{\text {th }}$ August, 2018).

The sentiments of the school principal conform with studies which found that through learner-centred approaches, students are also encouraged to acquire autonomous behavior, and be visionary and responsible in creating peaceful environments and that transformative approaches equipped students with the ability to engage in problem solving processes to avert conflict.

Bar Tal cautions that teaching approaches which integrate peace content require open mindedness and experiential learning and is also largely instructor dependent. Although this perspective shows preference to teacher based teaching approaches at the expense of learner-based approaches, it allows for emphasis on content delivery which is just as critical. In many of the developed countries, the pedagogy involves personalized interaction with students to enable talent nurturing, critical and creative thinking, tolerance and conflict resolution skills for solving problems encountered in life without use of violence (Bar-Tal et al., 2009).

\subsection{Participatory Teaching Approaches}

Participatory teaching approaches encourage interactions, improves retention of 
knowledge, enhances creative thinking, problem-solving skills and fosters collaborative learning. In order to find out if participatory methods were used by teachers in the delivery of PE content, the informants were asked to state the extent to which they agreed or not that the teachers used methods which allowed them to participate in the teaching and learning process. The responses were cross tabulated and results shown in Table 6.

Table 6 shows that majority of the respondents at $58.1 \%$ agreed that teachers used teaching techniques which allowed them to participate during the teaching and learning lessons with boys' boarding schools presenting the highest proportion at $15.0 \%$ followed by coeducational schools at $13.3 \%$ and girls' boarding at $11.8 \% .20 .1 \%$ of the informants were however undecided, implying that the use of these methods was not to the expectation of the learners. It further emerged from the FGDs that some learners participated in class while others did not. The discussants felt that more time was spent on lecturing and dictation of notes than on giving the learner an opportunity to take part in the learning process by asking questions, seeking clarifications or doing an activity to enhance learning. They were of the opinion that interactions with one another and their teacher was limited and that a conducive environment to allow for open discussions and exchange of ideas amongst students was lacking in some cases. The classroom environment and the school community as a whole should nurture respectful relationships and team work among students and other members.

Table 6. Use of participatory teaching approaches by categories of schools.

\begin{tabular}{|c|c|c|c|c|c|c|c|c|}
\hline \multirow{2}{*}{$\begin{array}{c}\text { Level of } \\
\text { Agreement }\end{array}$} & \multicolumn{7}{|c|}{ Category of School } & \multirow{2}{*}{ Total } \\
\hline & BB & GB & $\mathrm{BD}$ & GD & $\mathrm{CD}$ & $\mathrm{CD} \& \mathrm{~B}$ & $\mathrm{BB} \& \mathrm{D}$ & \\
\hline \multirow{2}{*}{$\begin{array}{c}\text { Strongly } \\
\text { Agree }\end{array}$} & 20 & 16 & 10 & 5 & 21 & 2 & 5 & 79 \\
\hline & $5.0 \%$ & $4.0 \%$ & $2.5 \%$ & $1.3 \%$ & $5.3 \%$ & $0.5 \%$ & $1.3 \%$ & $19.8 \%$ \\
\hline \multirow[b]{2}{*}{ Agree } & 40 & 31 & 28 & 10 & 32 & 6 & 6 & 153 \\
\hline & $10.0 \%$ & $7.8 \%$ & $7.0 \%$ & $2.5 \%$ & $8.0 \%$ & $1.5 \%$ & $1.5 \%$ & $38.3 \%$ \\
\hline \multirow[b]{2}{*}{ Undecided } & 15 & 20 & 16 & 5 & 20 & 2 & 2 & 80 \\
\hline & $3.8 \%$ & $5.0 \%$ & $4.0 \%$ & $1.3 \%$ & $5.0 \%$ & $0.5 \%$ & $0.5 \%$ & $20.1 \%$ \\
\hline \multirow{2}{*}{ Disagree } & 14 & 15 & 5 & 1 & 22 & 3 & 1 & 61 \\
\hline & $3.5 \%$ & $3.8 \%$ & $1.3 \%$ & $0.3 \%$ & $5.5 \%$ & $0.8 \%$ & $0.3 \%$ & $15.3 \%$ \\
\hline \multirow{2}{*}{$\begin{array}{l}\text { Strongly } \\
\text { Disagree }\end{array}$} & 8 & 3 & 3 & 0 & 10 & 0 & 2 & 26 \\
\hline & $2.0 \%$ & $0.8 \%$ & $0.8 \%$ & $0.0 \%$ & $2.5 \%$ & $0.0 \%$ & $0.5 \%$ & $6.5 \%$ \\
\hline \multirow{2}{*}{ Total } & 97 & 85 & 62 & 21 & 105 & 13 & 16 & 399 \\
\hline & $24.3 \%$ & $21.3 \%$ & $15.5 \%$ & $5.3 \%$ & $26.3 \%$ & $3.3 \%$ & $4.0 \%$ & $100.0 \%$ \\
\hline
\end{tabular}

BB-Boys' Boarding; GB-Girls' Boarding; BD—Boys' Day; GD—Girls' Day; CD—Coeducational day; CDD\&B-Coeducational Day \& Boarding; BB\&D-Boys' Boarding \& Day. 
Teachers should ensure the learners are actively involved in the process of learning and the process is experiential to enable change of attitude. When this is not achieved, learning does not nurture peace values and this may lead to violence. The findings are related to the views of (Shah \& Meinshenberg, 2017) that teaching peace is not like teaching Mathematics and English, which largely involves the acquisition of knowledge and skills on the subject content, without having to internalize the values. The aim of PE is to inculcate the desire for peace and respect for others.

\subsection{Group Discussions}

Group discussions allow participants to express their views on a particular topic. The task to be performed and the expected outcomes should be made very clear to all the participants of the group. The discussions enable participants to experience diversity of opinions on an issue and socially promotes cohesion, cooperation and mutual respect for one another. In order to establish the extent to which group discussions were used by teachers as a way of encouraging team work and cohesion, the informants were asked to state the extent to which they agreed or not that group discussions were used during the learning and teaching sessions. The responses were cross tabulated and results shown in Table 7.

Table 7 shows that majority of the respondents at $87.7 \%$ agreed that teachers used group discussions as a teaching technique, $4.0 \%$ were undecided and only

Table 7. Use of group discussions as a teaching approach.

\begin{tabular}{ccccccccc}
\hline \multirow{2}{*}{$\begin{array}{c}\text { Level of } \\
\text { Agreement }\end{array}$} & BB & GB & BD & GD & CD & CD\&B & BB\&D & Total \\
\cline { 2 - 6 } $\begin{array}{c}\text { Strongly } \\
\text { Agee }\end{array}$ & 58 & 67 & 42 & 18 & 62 & 5 & 10 & 262 \\
& $13.7 \%$ & $15.9 \%$ & $10.0 \%$ & $4.3 \%$ & $14.7 \%$ & $1.2 \%$ & $2.4 \%$ & $62.1 \%$ \\
Agree & 24 & 16 & 15 & 3 & 38 & 8 & 4 & 108 \\
& $5.7 \%$ & $3.8 \%$ & $3.6 \%$ & $0.7 \%$ & $9.0 \%$ & $1.9 \%$ & $0.9 \%$ & $25.6 \%$ \\
Undecided & 8 & 0 & 3 & 0 & 5 & 0 & 1 & 17 \\
& $1.9 \%$ & $0.0 \%$ & $0.7 \%$ & $0.0 \%$ & $1.2 \%$ & $0.0 \%$ & $0.2 \%$ & $4.0 \%$ \\
Disagree & 3 & 2 & 4 & 0 & 2 & 1 & 0 & 12 \\
& $0.7 \%$ & $0.5 \%$ & $0.9 \%$ & $0.0 \%$ & $0.5 \%$ & $0.2 \%$ & $0.0 \%$ & $2.8 \%$ \\
Strongly & 8 & 5 & 1 & 0 & 6 & 0 & 3 & 23 \\
Disagree & $1.9 \%$ & $1.2 \%$ & $0.2 \%$ & $0.0 \%$ & $1.4 \%$ & $0.0 \%$ & $0.7 \%$ & $5.5 \%$ \\
& 101 & 90 & 65 & 21 & 113 & 14 & 18 & 422 \\
\hline Total & $23.9 \%$ & $21.3 \%$ & $15.4 \%$ & $5.0 \%$ & $26.8 \%$ & $3.3 \%$ & $4.3 \%$ & $100.0 \%$ \\
\hline
\end{tabular}

BB-Boys' Boarding; GB-Girls’ Boarding; BD-Boys' Day; GD—Girls' Day; CD—Coeducational day; CDD\&B-Coeducational Day \& Boarding; BB\&D-Boys' Boarding \& Day. 
8.3\% felt that they were not in use. Further, findings from the FGDs confirmed that group discussions were used by teachers. It however emerged that in many instances, teachers did not oversee the formation of these groups and as such the group dynamics were not taken into account. One of the discussants said:

"Yes, our teachers occasionally ask us to form groups. We like to choose to be with our friends in such groups. We then are supposed to discuss class assignment and then we present in class. Everyone should participate in the group discussion and the group has a leader. Sometimes we fail to meet in our groups but we like it because we are free to talk to one another" (Male

Form one student, BD school, FGD 5, $12^{\text {th }}$ July, 2018)

These remarks suggest that the learners like group discussions and they are aware of the benefits but it is evident that the teachers don't pay sufficient attention to the groups even at the formation phase which calls for skillful mixing of abilities and personality traits. They do not supervise the activities that take place in these groups and as a result the group discussions do not achieve the intended purpose of encouraging teamwork, cohesion and interactions within the groups so as to enhance relationships of the members of the group. In a study on the importance of group discussions, it was noted that participants in a group convene to discuss an issue with the intention of finding a solution in the event that there is a problem (Nagarathinam \& Lakshmanan, 2016). It is, therefore, expected that when students respect one another's opinion and practice to speak one a time in alternating turns during the discussions they learn to be respectful. Teaching and learning activities which provide an opportunity for leaners to freely interact and share their diverse views should be used. This encourages getting to know and understand each another much better and in so doing they not only learn to respect one another but also to resolve conflicts amicably for the sake of peaceful coexistence.

\section{Classroom Observations of Teaching Approaches}

To complement the perceptions of the teachers and the learners, the study conducted independent classroom observations were necessary to visualize the teaching methods used by the teachers and the conduciveness of the classroom environment. The focus was on the teaching of History \& Government and CRE because studies have shown that these subjects contain more PE content (Opere et al., 2019). It was possible to observe History \& Government and CRE lessons in various categories of schools as shown in the Table 8.

Table 8 shows the seven categories of schools, specific class levels and the subjects observed. The findings are indicated in Table 9.

Table 9 illustrates the outcome of the classroom observations. It is apparent that teachers spent more time on the lecture method of teaching. Dictation and note taking was also preferred to learner centred techniques such as role play. In three out of the seven schools the learners' participation in the lesson was by way 
of a question and answer session and in only one school was oral presentations done. In both instances, the question and answer technique was used at the end of the lesson to obtain feedback on the extent to which the learners have understood the subject content delivered during that lesson. The teachers also asked questions at the beginning of the lesson to recap the previous lesson and introduce the current one. Contrary to the views of the learners that teachers

Table 8. Classroom observation schedule.

\begin{tabular}{ccc}
\hline Subject & School Category & Class level \\
\hline CRE & BB & Forms 1 \\
& GB & Form 2 \\
& GD & Form 4 \\
\hline History \& Government & BD & Forms 1 \\
& $\mathrm{CD}$ & Form 2 \\
& $\mathrm{BB} / \mathrm{D}$ & Form 3 \\
\hline
\end{tabular}

Source: Authors' own compilation. BB-Boys' Boarding; GB-Girls' Boarding; BD—Boys' Day; GD—Girls' Day; CD—Coeducational day; CDD\&B-Coeducational Day \& Boarding; BB\&D—Boys' Boarding \& Day.

Table 9. Summary of observations/findings of teaching approaches used seven schools.

\begin{tabular}{|c|c|c|c|c|c|c|c|c|c|}
\hline \multirow{2}{*}{ Classroom activities/Indicators } & \multicolumn{7}{|c|}{ Time spent on the activity } & \multirow{2}{*}{$\%$} & \multirow{2}{*}{$\begin{array}{l}\text { Cumulative Actual } \\
\text { Time Spent on the } \\
\text { activity in Minutes }\end{array}$} \\
\hline & $\mathrm{BB}$ & GB & GD & $\mathrm{BD}$ & $\mathrm{CD}$ & $\mathrm{BB} \& \mathrm{D}$ & $\mathrm{CDD} \& \mathrm{~B}$ & & \\
\hline Dictation of notes by the teacher & 5 & 12 & 10 & 16 & 10 & 25 & 0 & 27.8 & 78 \\
\hline Lecturing & 10 & 10 & 12 & 13 & 18 & 5 & 20 & 30.2 & 84 \\
\hline $\begin{array}{l}\text { Writing on chalk board as } \\
\text { students take notes }\end{array}$ & 12 & 10 & 15 & 6 & 8 & 0 & 12 & 23.9 & 67 \\
\hline Question and Answer & 7 & 8 & 3 & 5 & 4 & 10 & 8 & 16.1 & 45 \\
\hline Inter-student Discussion & 6 & 0 & 0 & 0 & 0 & 0 & 0 & 0 & 0 \\
\hline Role Play & 0 & 0 & 0 & 0 & 0 & 0 & 0 & 0 & 0 \\
\hline Drama & 0 & 0 & 0 & 0 & 0 & 0 & 0 & 0 & 0 \\
\hline Songs/Poems & 0 & 0 & 0 & 0 & 0 & 0 & 0 & 0 & 0 \\
\hline Class demonstrations & 0 & 0 & 0 & 0 & 0 & 0 & 0 & 0 & 0 \\
\hline Oral Presentations & 0 & 0 & 0 & 0 & 0 & 0 & 0 & 0 & 0 \\
\hline Group Discussions & 0 & 0 & 0 & 0 & 0 & 0 & 0 & 0 & 0 \\
\hline Total & 40 & 40 & 40 & 40 & 40 & 40 & 40 & 100 & 280 \\
\hline
\end{tabular}

Source: Author's own compilation. BB-Boys' Boarding; GB—Girls' Boarding; BD—Boys' Day; GD—Girls' Day; CD—Coeducational day; CDD\&B-Coeducational Day \& Boarding; BB\&D-Boys' Boarding \& Day. 
used participatory methods of teaching, it was observable that the lecture method of teaching was dominantly used. The outcome of the actual observation therefore contradicted the perceptions of the respondents in this regard.

\section{Summary and Conclusion of Findings}

It was realized that teacher centred teaching approaches were popularly used. To some extent participatory techniques of teaching involving group discussions were used but lacked the required supervision by teachers and as result failed to achieve the desired objectives. The use of transformative teaching approaches focusing on realistic experiences which lead to enhanced self-awareness and a desire for peaceful coexistence was limited. It was enabling the learners to appreciate a spirit of team work, harmony, cohesion and hence peaceful coexistence. Teacher centred approaches such as lecture method, dictation and note taking from the chalkboard were popularly used because the teachers considered such methods less time consuming and requiring minimal teaching and learning resources. An examination oriented mode of teaching with constant reference to skills of scoring high grades diverted attention from the PE content that required to be highlighted. Some teachers complained of lack of space for group discussions or role play. Observing the teaching and learning sessions it was evident that teachers failed to deliberately single out peace values for the sake of laying emphasis on them. The study found out that through transformative approaches the students' ability to solve problems, rejection of ethnicity and sexual discrimination and appreciation of cultural diversity were enhanced and it was therefore possible to achieve cohesive and violence free school communities.

The paper concluded that the more effectively the transformative learning approaches are applied in public secondary schools, the better well behaved the students become hence no or limited school unrests are likely to be experienced hence the importance of putting them into practice. The paper has finally recommended that transformative pedagogy should be used to inculcate peace values in learners for the sake of peaceful coexistence. Teachers should be trained on how to infuse peace values in their respective subjects. This is because their inability to integrate PE content was evident. Besides they will acquire skills on the use of experiential teaching approaches to inculcate peace values.

\section{Conflicts of Interest}

The authors declare no conflicts of interest regarding the publication of this paper.

\section{References}

Bar-Tal, D., Chernyak-Hai, L., Schori, N., \& Gundar, A. (2009). A Sense of Self-Perceived Collective Victimhood in Intractable Conflicts. International Review of the Red Cross, 91, 229-258. https://doi.org/10.1017/S1816383109990221

Bartlett, J. E., Kotrlik, J. W., \& Higgs, C. C. (2001). Organizational Research: Determining Appropriate 12. 
Creswell (2014). Research Design. Qualitative, Quantitative, and Mixed Methods Approaches (4th ed.). Thousand Oaks, CA: Sage Publications.

Darling-Hammond, L., Flook, L., Cook-Harvey, C., Barron, B., \& Osher, D. (2020). Implications for Educational Practice of the Science of Learning and Development. Applied Developmental Science, 24, 97-140. https://doi.org/10.1080/10888691.2018.1537791

Hermino, A. (2017). Peace Education and Child Protection in Educational Settings for Elementary School in the West Papua of Indonesia. Asian Social Science, 13, 20-31. https://doi.org/10.5539/ass.v13n8p20

Kirioba, M. T. (2012). The Secondary School Social Environment and Student Violence in Kenya. Elixir International Journal, 46, 8100-8104.

Krejcie, R. V., \& Morgan, D. W. (1970). Determining Sample Size for Research Activities. Educational and Psychological Measurement, 30, 607-610. https://doi.org/10.1261/rna.2763111

Laryea, K. (2018). A Pedagogy of Deep Listening in e-Learning. Journal of Conscious Evolution, 11, 2.

McAllister, M. (2015). Exploring Transformative Learning and the Courage to Teach a Values Based Curriculum. Nurse Education in Practice, 15, 480-484. https://doi.org/10.1016/j.nepr.2015.01.007

Mezirow, J. (2009). Transformative Learning Theory. In J. Mezirow, \& E. W. Taylor (Eds.), Transformative Learning in Practice: Insights from Community Workplace, and Higher Education (pp. 18-32). San Francisco, CA: Jossey-Bass.

Nagarathinam, D., \& Lakshmanan, P. L. (2016). New Perspectives in ELT the Importance of Group Discussion and the Role of Participants. New Perspectives in ELT, 16, 169 \& 179.

Olowo, O. O. (2016). Effects of Integrating Peace Education in the Nigeria Education System. Journal of Education and Practice, 7, 9-14.

Opere, O., Kamere, I., \& Violet, W. (2019). School Violence as a Cause of Non-Peaceful Coexistence in Public Secondary Schools in Nairobi, Kenya. Open Journal of Social Sciences, 7, 130-145. https://doi.org/10.4236/jss.2019.79010 https://www.scirp.org/journal/paperinformation.aspx?paperid=95131

Pherali, T. (2019). Theories and Conceptual Frameworks in Education, Conflict and Peace-Building. Education and Conflict Review, 2, 12.

Shah, S., \& Meinshenberg, G. (2017). Teaching Peace along with Routine Education: A Simple and Easy to Implement Strategy for a Peaceful Happy World. Issues and Ideas in Education, 5, 87-102. https://doi.org/10.15415/iie.2017.51006

Taka, M. (2020). The Role of Education in Peace-Building: Learner Narratives from Rwanda. Journal of Peace Education, 17, 107-122. https://doi.org/10.1080/17400201.2019.1669146 